\title{
The assessment of the perinatal outcomes of the patients who underwent quad screening test
}

\author{
Mehmet Mete Kırlangıç (D), Gökhan Açmaz (D), Erdem Şahin (iD, Yusuf Madendağ (D), \\ Fatma Özdemir (D), İptisam İpek Müderris \\ Department of Gynecology and Obstetrics, Faculty of Medicine, Erciyes University, Kayseri, Turkey
}

\begin{abstract}
Objective: The aim of this study is to assess the correlation between the poor perinatal outcomes and the serum biochemical markers such as maternal serum alpha fetoprotein (AFP), human chorionic gonadotropin (hCG), unconjugated estriol (uE3) and inhibin-A (INHA) checked during the quad screening test.

Methods: In this retrospective study, the results of 485 pregnant women who underwent quad screening test in the Outpatient Clinic of Gynecology and Obstetrics of Faculty of Medicine at Erciyes University, Kayseri, Turkey between January 2018 and January 2019 and met the inclusion criteria were analyzed. The primary result of the study was established as the development of poor perinatal outcomes. The poor perinatal outcomes were defined as gestational diabetes (GDM), gestational hypertension (GHT), preeclampsia, intrauterine growth restriction (IUGR), preterm labor, premature rupture of membranes (PRM), oligohydramnios, polyhydramnios, HELLP syndrome, and intrahepatic cholestasis of pregnancy (ICP).

Results: A total of 485 pregnant women, who met the inclusion criteria, were included in the study. A significant correlation was found between AFP $M o M \geq 2$ and GHT, PRM, preterm labor, and the development of IUGR ( $\mathrm{p}=0.017, \mathrm{p}=0.033, \mathrm{p}=0.037$, and $\mathrm{p}=0.038$, respectively). It was seen that the risk increased 5.1 times for GHT, 3.2 times for preterm labor, and 3.8 times for the development of IUGR. There was a significant correlation between $\mathrm{hCG} M \mathrm{MoM} \geq 2$ and the risk of GHT development ( $\mathrm{p}=0.024)$; however, the risk of GHT development increased for 3.8 times above this value. A significant correlation was found between INH-A being $M o M \geq 2$ and the development of GHT and HELLP syndrome ( $\mathrm{p}=0.009$ and $\mathrm{p}=0.005$, respectively). In these pregnant women, the risk increased 31 times for the development of HELLP syndrome, and 9.4 times for GHT. In the cases with $\mathrm{uE} 3 \mathrm{MoM} \leq 0.5$, there was a significant correlation for the development of preeclampsia and HELLP syndrome ( $\mathrm{p}=0.033$ and $\mathrm{p}=0.049$, respectively). On the other hand, there was no significant correlation between GDM, ICP, polyhydramnios, and oligohydramnios and AFP MoM, beta-hCG MoM, uE3 MoM and INH-A MoM values.

Conclusion: In our study, we found correlation between poor perinatal outcomes and the changes in AFP, hCG, $\mathrm{uE} 3$ and INH-A levels.
\end{abstract}

Keywords: AFP, quad screening test, hCG, inhibin-A, perinatal outcome, uE3.

\section{Özet: Dörtlü test yapılan hastaların perinatal sonuçlarının değerlendirilmesi}

Amaç: Bu çalışmanın amacı, dörtlü test sırasında değerlendirilen maternal serum alfa fetoprotein (AFP), insan koryonik gonadotropini (hCG), unkonjuge estriol ( $\mathrm{uE3}$ ) ve inhibin-A (INH-A) serum biyokimyasal belirteçleri ile olumsuz perinatal sonuçlar arasındaki ilişkiyi değerlendirmektir.

Yöntem: Bu retrospektif çalışmada Ocak 2018 - Ocak 2019 tarihleri arasında Erciyes Üniversitesi Tıp Fakültesi Kadın Hastalıkları ve Doğum polikliniğinde dörtlü tarama testi yaptıran ve çalışmaya dahil edilme kriterlerini karşılayan 485 gebenin sonuçları analiz edildi. Çalışmanın primer sonucu olumsuz perinatal sonuçların gelişmesi olarak belirlendi. Olumsuz perinatal sonuçlar gestasyonel diyabet (GDM), gestasyonel hipertansiyon (GHT), preeklampsi, intrauterin gelişim geriliği (IUGR), preterm doğum, erken membran rüptürü (EMR), oligohidroamniyoz, polihidroamniyoz, HELLP sendromu, gebeliğin intrahepatik kolestazı (GİK) olarak tanımland.

Bulgular: Çalışmaya, dahil edilme kriterlerini karşılayan 485 gebe çalışmaya dahil edildi. AFP'nin $M o M \geq 2$ olması ile GHT, EMR, preterm doğum, IUGR gelişimi arasında anlamlı ilişki bulundu (sirasiyla $\mathrm{p}=0.017, \mathrm{p}=0.033, \mathrm{p}=0.037, \mathrm{p}=0.038$ ). $\mathrm{GHT}$ riskinde 5.1 kat, preterm doğum riskinde 3.2 kat, IUGR gelişme riskinde 3.8 kat artış olduğu görüldü. hCG'nin $\mathrm{MoM} \geq 2$ olması ile GHT gelişme riski arasında anlamlı ilişki bulundu $(\mathrm{p}=0.024)$; bu değerin üstünde GHT gelişme riskinde 3.8 kat artış olduğu tespit edildi. INH-A'nın MoM $\geq 2$ olması ile GHT, HELLP sendromu gelişimi açısından anlamlı ilişki saptandı (sırasıyla p=0.009, $\mathrm{p}=0.005$ ). $\mathrm{Bu}$ gebelerde HELLP sendromu gelişme riskinde 31 kat, GHT riskinde 9.4 kat artış tespit edildi. uE3 MoM değeri $\leq 0.5$ olanlarda preeklampsi ve HELLP sendromu gelişiminde anlamlı ilişki olduğu görüldü (sırasıyla p=0.033, p=0.049). Ek olarak GDM, GİK, polihidroamniyoz ve oligohidroamniyoz ile AFP MoM, beta-hCG MoM, uE3 MoM ve INH-A MoM değerleri arasında anlamlı korelasyon saptanmadi.

Sonuç: Çalışmamızda AFP, hCG, uE3, INH-A seviyelerindeki değişim ile kötü perinatal sonuçlar arasında ilişki bulunduğu görülmüştür.

Anahtar sözcükler: AFP, dörtlü test, hCG, inhibin-A, perinatal sonuç, $\mathrm{uE} 3$.

Correspondence: Yusuf Madendağ, MD. Department of Gynecology and Obstetrics, Faculty of Medicine, Erciyes University, Kayseri, Turkey. e-mail: yusufmadendag@gmail.com / Received: February, 29 2020; Accepted: April 8, 2020

Please cite this article as: Kırlangıç MM, Açmaz G, Şahin E, Madendă̆ Y, Özdemir F, Müderris III. The assessment of the perinatal outcomes of the patients who underwent quad screening test. Perinatal Journal 2020;28(1):28-35. doi:10.2399/prn.20.0281007 


\section{Introduction}

The purpose of prenatal diagnosis today is to detect genetic diseases and congenital anomalies of fetus before birth. The genetic tests performed for the diagnosis include cytogenetic tests and molecular tests which evaluate mutation analyses at DNA level. Thanks to the prenatal diagnosis, it is possible to establish intrauterine diagnosis in pregnancies with risk, and it also enables to initiate treatment disease, if any, before labor and to manage treatment after labor by taking necessary precautions. The serum biochemical markers such as maternal serum alpha fetoprotein (AFP), human chorionic gonadotropin (hCG), unconjugated estriol $(\mathrm{uE} 3)$ and inhibin-A (INH-A) are used to screen for aneuploidies such as trisomy 21 , trisomy 18 and trisomy 13 , and congenital anomalies such as neural tube defects in the second trimester. ${ }^{[1-3]}$ The correlation of positive prenatal screening tests with the congenital anomalies such as anterior abdominal wall defects and neural tube defect has been shown clearly. ${ }^{[4-6]}$ In addition, some studies reported that these serum biochemical markers may be correlated with poor perinatal outcomes in the fetuses without aneuploidy and congenital anomaly. ${ }^{[4,6,7]}$

In our study, we aimed to investigate the correlation between poor perinatal outcomes and the secondtrimester serum markers, which are out of the determined threshold ranges, of fetuses without aneuploidy and congenital anomaly.

\section{Methods}

This retrospective study was carried out in accordance with the Declaration of Helsinki by the approval of the Ethics Committee (2019/632) of the Department of Gynecology and Obstetrics of Faculty of Medicine, Erciyes University. The results of 889 pregnant women who underwent quad screening test in the obstetrics clinic between January 2018 and January 2019 were analyzed in the study. Multiple pregnancies, the pregnant women with congenital anomaly such as chromosomal anomaly, neural tube defect (NTD) and anterior abdominal wall defects during the follow-up, the pregnant women who had abortion before 24 weeks of gestation during the follow-up and those whose labor data could not be accessed were excluded from the study. After the final analysis, 485 pregnant women who underwent their quad screening tests, antenatal follow-ups and labors in our clinic and whose labor data could be accesses were included in the study.

Of the patients, the demographic characteristics, age, gravida, parity, early pregnancy loss, number of living child, gestational age at which quad screening test was performed, body weight, AFP, hCG, uE3, INH-A MoM levels, week of gestation, labor type, reason for cesarean section if any, birth weight, 1-minute and 5-minute Apgar scores, and blood gas values measured through cord blood at birth were accessed from the records. The gestational ages were calculated on the basis of the last menstrual dates of the patients, and ultrasound results were used to calculate the gestational ages for those whose last menstrual dates were unknown. For the cases without early period ultrasonography results, the biparietal diameter (BPD) during the test was based on.

All maternal markers were evaluated by solid-phase competitive immunoassay method. The blood samples were collected through antecubical vein between 15 and 20 weeks of gestation. The blood samples were kept at the room temperature for the coagulation for 20-30 minutes, and then they were processed by centrifuging at $3000 \mathrm{rpm}$ for 5 minutes. AFP values were reported in $\mathrm{IU} / \mathrm{ml}$, hCG values in $\mathrm{mIU} / \mathrm{ml}, \mathrm{uE} 3$ values in $\mathrm{ng} / \mathrm{ml}$, and INH-A values in $\mathrm{pg} / \mathrm{ml}$. The values were adapted to the body weights of the patients. The results were analyzed by using licensed SsdwLab 5 software (SBP SOFT, Girona, Spain), and the MoM value predetermined according to the weeks of gestation and risk rates for age, trisomy 21, trisomy 13, and trisomy 18 were reported. For test calculation, the risk was calculated by using the age, weight, smoking habit, diabetes and previous history of child with anomaly, IVF pregnancy, sample collection date and ultrasound date of the patients.

The primary result of the study was determined as the development of poor perinatal outcomes. The poor perinatal outcomes were defined as gestational diabetes (GDM), gestational hypertension (GHT), preeclampsia, intrauterine growth restriction (IUGR), preterm labor, premature rupture of membranes (PRM), oligohydramnios, polyhydramnios, HELLP syndrome, and intrahepatic cholestasis of pregnancy (ICP). The cases with glucose level $>180$ at 1 st hour after 50-g OGGT were considered GDM. The patients with glucose level $>140$ $\mathrm{mg} / \mathrm{dl}$ underwent 3-hour diagnosis test by 100-g OGTT. The 100 -g OGTT values being 2 or more (preprandial $\geq 95 \mathrm{mg} / \mathrm{dl}$, 1 st hour $\geq 180 \mathrm{mg} / \mathrm{dl}$, 2nd hour $\geq 155 \mathrm{mg} / \mathrm{dl}$, 3rd hour $\geq 140 \mathrm{mg} / \mathrm{dl}$ ) were accepted as GDM. ${ }^{[8]}$ GHT 
was defined as two blood pressure values measured with 6-hour interval being $>140 / 90 \mathrm{mmHg}$ without proteinuria. ${ }^{[9]}$ Preeclampsia was considered as the hypertension in a pregnant woman at the 20 weeks of gestation, who was previously normotensive (systolic blood pressure $\geq 140 \mathrm{mmHg}$ or diastolic blood pressure $\geq 90 \mathrm{mmHg}$ for 2 times with at least 4-hour interval, and systolic blood pressure $\geq 160 \mathrm{mmHg}$ or diastolic blood pressure $\geq 110$ $\mathrm{mmHg}$ for 2 times with a few minutes of interval) with concomitant proteinuria $(\geq 0.3 \mathrm{~g}$ proteinuria in $24-\mathrm{h}$ urine or $2+$ or more proteinuria in spot urine if quantitative measurement is not possible) or target organ dysfunction (platelet count $<100,000 / \mathrm{mm}^{3}$, serum creatinine $>1.1$ $\mathrm{mg} / \mathrm{dl}$ or double amount of serum creatinine without any other renal disease, liver transaminases being at least 2 times more than normal concentrations, pulmonary edema, cerebral symptoms). ${ }^{[9]}$ When amniotic membranes were ruptured before 37 weeks of gestation, it was considered PRM. The preterm labor was defined as the fulfilment of the labor by the cervical dilation and effacement accompanying to uterine contractions before 37 weeks of gestation. Except those which were constitutional and below 10th percentile according to the growth curves based on the estimated fetal weight (EFW) measured by the ultrasonography, the pregnancies presenting progressive deviation from the growth curve during 3week follow-up and having concomitant oligohydramnios and pathological fetal Doppler findings were defined as IUGR. ${ }^{[10]}$ Oligohydramnios and polyhydramnios were defined as the amniotic fluid index being $\leq 5 \mathrm{~cm}$ and $\geq 25 \mathrm{~mm}$, respectively. ${ }^{[1]}$ ICP was defined as the elevation in liver enzyme levels or bile acid levels due to the rash began in the third trimester of pregnancy. ${ }^{[12]}$ HELLP syndrome was diagnosed according to Mississippi criteria. AST or ALT values being $\geq 70 \mathrm{IU} / \mathrm{l}$, $\mathrm{LDH} \geq 600 \mathrm{IU} / \mathrm{l}$, and platelet count being 100,000 150,000 were accepted as HELLP syndrome. ${ }^{[13]}$ Based on the cut-off values in the literature, the patients with AFP $M o M \geq 2$, beta-hCG $M o M \geq 2$, INH-A MoM $\geq 2$ and $\mathrm{uE} 3 \mathrm{MoM} \leq 0.5$ were identified, and the presence of correlation between these patients and gestational complications (GDM, GHT, preeclampsia, IUGR, preterm labor, PRM, oligohydramnios, polyhydramnios, HELLP syndrome, ICP) was investigated.

\section{Statistical analysis}

Histogram and q-q plot graphics as well as Shapiro-Wilk test were used to test the normality of data in the statis- tical analysis. Levene's test statistics was used to check the homogeneity of the variances. The descriptive statistics were presented as mean, standard deviation, and minimum and maximum values. The differences between the groups in terms of mean values were analyzed by t-test and Mann-Whitney $\mathrm{U}$ test for the continuous variables and by Pearson's chi-squared test for the categorical variables. The values of AFP MoM, HCG MoM, INH-A MoM and uE3 MoM variables causing risks in terms of other variables were compared. The risks were presented by odds ratios and confidence intervals. All statistical analyses were conducted by TURCOSA Analitik software (https://turcosa.com.tr/; Turkosa Analitik, Kayseri, Turkey). For the statistical significance, $\mathrm{p}$-value was determined 0.05 .

\section{Results}

A total of 485 pregnant women who met inclusion criteria were included in the study after the final analysis. The demographic characteristics of the pregnant women are shown in Table 1 . The mean values of adjusted maternal serum AFP MoM, hCG MoM, uE3 MoM and INH-A $\mathrm{MoM}$ are presented in Table 2. The distribution of poor perinatal outcomes of 485 pregnant women in the study are given in Fig. 1. Of 485 pregnant women, 161 (34\%) delivered by normal labor while $324(66 \%)$ by cesarean section. Of the pregnant women, $30(6 \%)$ had GDM, 19 (3.9\%) had GHT, 46 (9.4\%) had PRM, 35 (7.2\%) had preterm labor, 27 (5.5\%) had IUGR, 19 (3.9\%) had preeclampsia, $18(3.7 \%)$ had polyhydramnios, 17 (3.5\%) had oligohydramnios, $2(0.4 \%)$ had cholestasis and 5 (1\%) had HELLP syndrome.

The correlation between poor perinatal outcomes and biochemical markers, and the values for risk increase in the poor perinatal outcomes are shown in Tables 3 and 4. There was no significant correlation between GDM, ICP, polyhydramnios, and oligohydramnios and AFP MoM, hCG MoM, uE3 MoM and INH-A MoM values.

There was a significant correlation between AFP $M o M \geq 2$ and the development of GHT, PRM, preterm labor and IUGR $(\mathrm{p}=0.017, \mathrm{p}=0.033, \mathrm{p}=0.037$, and $\mathrm{p}=0.038$, respectively). It was found that the risk increased 5.1 times for GHT (OR 1.578-16.713; $\mathrm{p}=0.010), 3.2$ times for preterm labor (OR 1.147-9.166; $\mathrm{p}=0.027$ ), 3.8 times for the development of IUGR (OR 1.203-12.059; $\mathrm{p}=0.023$ ), and 2.9 times for PRM (OR 1.139-7.825; $\mathrm{p}=0.026$ ) when $\mathrm{AFP} \mathrm{MoM}$ was $\geq 2$. 
Table 1. The demographic characteristics of pregnant women.

\begin{tabular}{lcccc} 
& Mean & SD & Minimum & Maximum \\
Age & 30.08 & 6.409 & 17 & 46 \\
Weight $(\mathrm{kg})$ & 70.37 & 14.792 & 36 & 15 \\
Week of gestation & 16.49 & 1.084 & 1 & 20 \\
Gravida & 3.04 & 1.54 & 0 & 10 \\
Parity & 1.50 & 1.17 & 0 & 7 \\
Number of abortion & 0.53 & 0.94 & 0 & 6 \\
Number of living child & 1.41 & 1.09 & 24 & 6 \\
Week of gestation during labor & 38.03 & 2.06 & 536 & 42 \\
Birth weight (g) & 3162 & 578 & 3 & 4530 \\
1-minute Apgar & 7.93 & 0.478 & 6 & 8 \\
5-minute Apgar & 9.95 & 0.433 & 6.90 & 10 \\
Cord blood gas (mmHg) & 7.33 & 0.074 & 7.49 \\
\hline
\end{tabular}

SD: standard deviation.

There was a significant correlation between hCG $M o M \geq 2$ and the risk of GHT development ( $\mathrm{p}=0.024)$. It was found that the risk increased for 3.8 times for the development of GHT (OR 1.303-11.104; p=0.020) when hCG MoM was $\geq 2$. Similarly, we did not find a correlation between low hCG MoM values and poor gestational outcomes in our study.

There was a significant correlation between the development of GHT and HELLP syndrome, and INH-A $M o M ~ \geq 2$ ( $\mathrm{p}=0.009$ and $\mathrm{p}=0.005$, respectively). It was found that the risk increased for 31 times for the development of HELLP syndrome (OR 4.667-206.813; $\mathrm{p}<0.001)$ and 9.4 times for GHT (OR 2.331-38.215; $\mathrm{p}=$ $0.002)$.

A significant correlation was observed between $\mathrm{uE} 3$ $M o M \leq 0.5$ and the development of preeclampsia and HELLP syndrome ( $\mathrm{p}=0.030$ and $\mathrm{p}=0.050$, respectively).
Table 2. The adjusted maternal serum hCG, uE3, AFP and INH-A MoM values.

\begin{tabular}{lcccc} 
& Mean & SD & Minimum & Maximum \\
AFP MoM & 1.22 & 0.62 & 0.30 & 7.54 \\
hCG MoM & 1.12 & 0.74 & 0.14 & 7.71 \\
UE3 MoM & 0.67 & 0.25 & 0.10 & 1.95 \\
INH-A MoM & 0.74 & 0.45 & 0.19 & 3.79 \\
\hline
\end{tabular}

SD: standard deviation.

\section{Discussion}

Maternal AFP, hCG, uE3 and İNH-A serum biochemical markers are important parameters used in the screening of aneuploidies and congenital anomalies, and the changes in their levels provide information about the prognosis of pregnancy. In our study, we investigated the correlation between poor perinatal outcomes and

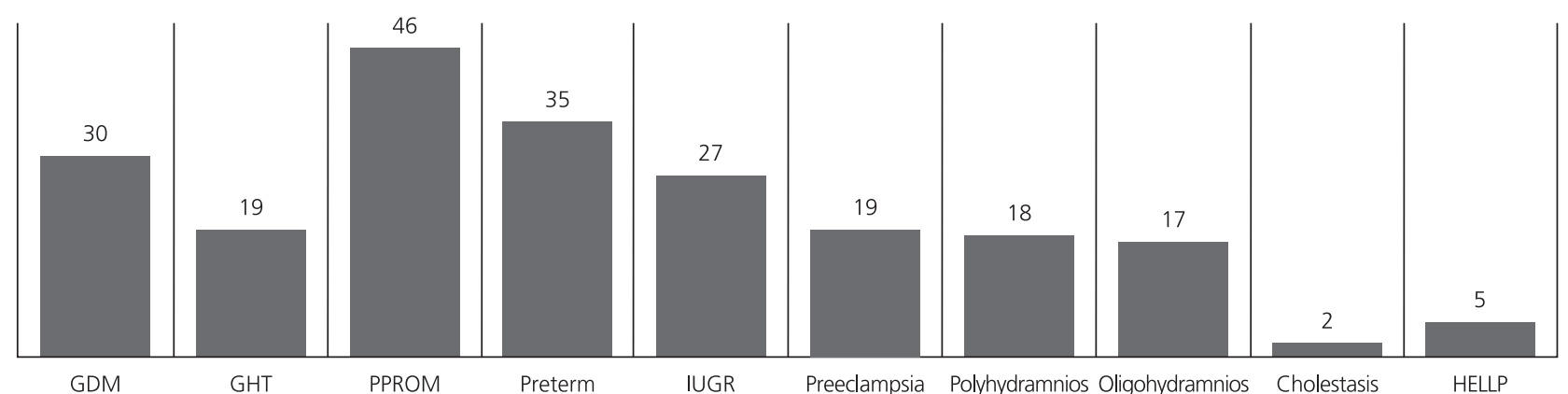

Fig. 1. The distribution of perinatal complications. 
Table 3. The correlation between poor perinatal outcomes and biochemical markers.

\begin{tabular}{|c|c|c|c|c|c|c|c|c|c|c|c|c|}
\hline \multirow{4}{*}{$\begin{array}{l}\text { Perinatal } \\
\text { complications }\end{array}$} & \multicolumn{3}{|c|}{ AFP MoM } & \multicolumn{3}{|c|}{ hCG MoM } & \multicolumn{3}{|c|}{ uE3 MoM } & \multicolumn{3}{|c|}{ INH-A MoM } \\
\hline & $<2$ & $\geq 2$ & & $<2$ & $\geq 2$ & & $>0.5$ & $\leq 0.5$ & & $<2$ & $\geq 2$ & \\
\hline & MolM & MolM & & MoM & MolM & & MoM & MolM & & MoM & MolM & \\
\hline & n (\%) & n (\%) & $p$ & n (\%) & n (\%) & p & n (\%) & n (\%) & p & n (\%) & n (\%) & p \\
\hline GDM & $29(6.0)$ & $1(0.2)$ & 0.490 & $28(5.8)$ & $2(0.4)$ & 0.459 & $16(3.3)$ & $14(2.9)$ & 0.138 & $29(6.2)$ & $0(0.0)$ & 0.470 \\
\hline GHT & $15(3.1)$ & $4(0.8)$ & 0.017 & $14(2.9)$ & $5(1.0)$ & 0.020 & $12(2.5)$ & $7(1.4)$ & 0.810 & $16(3.3)$ & $3(0.6)$ & 0.010 \\
\hline Preeclampsia & $18(3.9)$ & $1(0.2)$ & 0.714 & $17(3.5)$ & $2(0.4)$ & 0.540 & $8(1.6)$ & $11(2.3)$ & 0.030 & $17(3.5)$ & $1(0.2)$ & 0.370 \\
\hline IUGR & $23(4.7)$ & $4(0.8)$ & 0.038 & $20(4.1)$ & $4(0.8)$ & 0.170 & $14(4.9)$ & $10(6.0)$ & 0.430 & $21(4.5)$ & $3(0.6)$ & 0.180 \\
\hline PRM & $40(8.2)$ & $6(1.2)$ & 0.033 & $39(8.0)$ & $7(1.4)$ & 0.120 & $29(9.1)$ & $17(3.5)$ & 0.400 & $46(9.6)$ & $0(0.0)$ & 0.300 \\
\hline Preterm labor & $30(6.2)$ & $5(1.0)$ & 0.037 & $31(6.4)$ & $4(0.8)$ & 0.410 & $24(4.9)$ & $11(2.3)$ & 0.440 & $35(7.3)$ & $0(0.0)$ & 0.400 \\
\hline Oligohydramnios & $16(3.3)$ & $1(0.2)$ & 0.629 & $15(3.1)$ & $2(0.4)$ & 0.510 & $12(2.5)$ & $5(1.0)$ & 0.670 & $17(3.5)$ & $0(0.0)$ & 0.650 \\
\hline Polyhydramnios & $18(3.7)$ & $0(0.0)$ & 0.350 & $16(3.3)$ & $2(0.4)$ & 0.511 & $11(2.3)$ & $7(1.4)$ & 0.671 & $18(3.7)$ & $0(0.0)$ & 0.629 \\
\hline ICP & $2(0.4)$ & $0(0.0)$ & 0.892 & $2(0.4)$ & $0(0.0)$ & 0.820 & $2(0.4)$ & $0(0.0)$ & 0.430 & $2(0.4)$ & $0(0.0)$ & 0.950 \\
\hline HELLP syndrome & $0(0.0)$ & $5(1.0)$ & 0.750 & $3(0.6)$ & $2(0.4)$ & 0.070 & $1(0.2)$ & $4(0.8)$ & 0.050 & $3(0.6)$ & $2(0.4)$ & 0.010 \\
\hline
\end{tabular}

The values are presented as $\mathrm{n}(\%)$. Statistically significant $\mathrm{p}$-values are given in bold. GDM: gestational diabetes; GHT: gestational hypertension; ICP: intrahepatic cholestasis of pregnancy; IUGR: intrauterine growth restriction; PRM: premature rupture of membrane.

second trimester serum markers being out of predetermined cut-off ranges in the fetuses without aneuploidy and congenital anomaly. The results of our study showed that the serum markers assessed in the second trimester screening test can be used to detect aneuploidy and congenital anomalies as well as the pregnancies with high risk. We found in our study that AFP, hCG, uE3 and INH-A levels are correlated with the poor perinatal outcomes.

There are studies in the literature showing that the increased maternal serum AFP, hCG, INH-A and decreased $\mathrm{uE} 3$ levels which are among the second trimester markers can be compared with the poor obstetric outcomes in the advanced periods of pregnancy for the normal fetuses without aneuploidy or neural tube defect. ${ }^{[14]} \mathrm{AFP}$ is a oncofetal glycoprotein weighing $69 \mathrm{kDa}$. It is produced by secondary yolk sac beginning with the second month of the pregnancy and by fetal liver and gastrointestinal system after the third month of pregnancy. ${ }^{[15]}$ The conditions where AFP is $>2.5 \mathrm{MoM}$ in the pregnancies without placenta anomalies such as fetal chromosomal anomalies, structural anomalies (NTD, abdominal wall defect, etc.) and chorioangioma, and maternal conditions such as choriocarcinoma or

Table 4. Risk increase values in poor perinatal outcomes.

\begin{tabular}{|c|c|c|c|c|c|c|c|c|}
\hline \multirow{2}{*}{$\begin{array}{l}\text { Perinatal } \\
\text { complications }\end{array}$} & \multicolumn{2}{|c|}{ AFP MoM $\geq 2$ MoM } & \multicolumn{2}{|c|}{ beta-hCG MoM $\geq 2$ MoM } & \multicolumn{2}{|c|}{ uE3 MoM $\leq 0.5$ MoM } & \multicolumn{2}{|c|}{ INH-A MoM $\geq 2$ MoM } \\
\hline & OR $(95 \% \mathrm{Cl})$ & p & OR $(95 \% \mathrm{Cl})$ & $\mathbf{p}$ & OR $(95 \% \mathrm{Cl})$ & p & OR $(95 \% \mathrm{Cl})$ & $\mathbf{p}$ \\
\hline \multicolumn{9}{|l|}{ GDM } \\
\hline GHT & $5.136(1.578-16.713)$ & 0.010 & $3.804(1.303-11.104)$ & 0.020 & & & $9.437(2.331-38.215)$ & 0.002 \\
\hline Preeclampsia & & & & & $0.362(0.143-0.919)$ & 0.030 & & \\
\hline IUGR & 3.809 (1.203-12.059) & 0.023 & & & & & & \\
\hline PRM & $2.986(1.139-7.825)$ & 0.026 & & & & & & \\
\hline Preterm labor & $3.242(1.147-9.166)$ & 0.027 & & & & & & \\
\hline \multicolumn{9}{|l|}{ Oligohydramnios } \\
\hline \multicolumn{9}{|l|}{ Polyhydramnios } \\
\hline \multicolumn{9}{|l|}{ Cholestasis } \\
\hline HELLP syndrome & & & $6.775(1.102-41.666)$ & 0.039 & & & 31.067 (4.667-206.813) & $<0.001$ \\
\hline
\end{tabular}

Statistically significant p-values are given in bold. Cl: confidence interval; GDM: gestational diabetes; GHT: gestational hypertension; IUGR: intrauterine growth restriction; OR: odds ratio; PRM: premature rupture of membrane. 
ovary pathology are considered to be increased AFP level. Although the reason of this increased value is not clear, the authors in a study considered that there is pathology in chorionic villi or placental vascular structures. ${ }^{[16]}$ In our study, we found significant correlation between AFP MoM level being $\geq 2$ and the development of GHT, PRM, preterm labor and IUGR, and we found out that the risk increased for 5.1 times for GHT, 3.2 times for preterm labor, 3 times for IUGR development and 2.9 times for PRM. The results of our study are consistent with the other studies in the literature. Crandall et al. found significant correlation between AFP MoM level being $\geq 2$ and the development of GHT, PRM, preterm labor and IUGR, and they reported that the rate of obtaining poor perinatal outcome was $19 \%$ when MoM level was 2.5-2.9, and up to $70 \%$ when the MoM level was $>5{ }^{[17]}$ Another study reported that the incidence of GHT was significantly high with the increased AFP MoM levels, and the risk increased for 4 times. ${ }^{[3]}$

In our study, we found significant correlation for hCG MoM being $\geq 2$ only with the risk of developing GHT, and found out that the risk for developing GHT increased for 3.8 times when hCG MoM was $\geq 2$. Similarly, Gündüz et al. reported that there was a significant correlation between increased beta-hCG levels $(\geq 2$ $\mathrm{MoM}$ ) and the development of hypertension induced by the pregnancy and isolated fetal growth restriction, and they found that the risk increased 3 times for the hypertension induced by the pregnancy and 2 times for isolated fetal growth restriction. ${ }^{[3]}$ In another study, Walton et al. reported that there was a correlation between hCG levels and preterm labor and stillbirth. ${ }^{[18]}$ Similarly, Heionnen et al. showed in their study that there was a correlation between increased hCG level and IUGR, preeclampsia, and GHT. In our study, we found a significant correlation between hCG level and GHT, and reported that elevated hCG level increased the risk of developing GHT for 3.8 times. Although a significant correlation could not be found between HELLP syndrome and hCG MoM level, the regression analysis showed that the elevation in hCG MoM level increased the risk of developing HELLP syndrome for 6.7 times. ${ }^{[19]}$ In the literature, no correlation was shown between low hCG level and poor perinatal outcomes, ${ }^{[1,20]}$ and similarly, we did not found any correlation between low hCG MoM values and poor perinatal outcomes.

We observed a significant correlation between $\mathrm{uE3}$ $M o M \leq 0.5$ and the development of preeclampsia and
HELLP syndrome. $\mathrm{uE3}$ is synthesized from 16-alphahydroxy-DHEA-S, which is a fetal precursor, by syncytiotrophoblasts in the placenta. It is converted to 16alpha-hydroxy-DHEA-S by 16-alpha hydroxylase enzyme in the fetal liver. The product emerging after being deconjugated by the placental sulfatase enzyme is aromatized by the aromatase enzyme, and $\mathrm{uE} 3$ is obtained. ${ }^{[20]}$ A study showed that the low level of $\mathrm{uE3}$ is associated with fetal chromosomal anomalies, structural anomalies (anencephaly), fetal death or fetal metabolic conditions (steroid sulfatase deficiency, congenital adrenal hypoplasia, Smith-Lemli-Opitz syndrome) ${ }^{[21]}$ In the literature, Gündüz et al. showed that uE3 levels $(<0.5$ $\mathrm{MoM})$ are correlated with the poor perinatal outcomes. ${ }^{[3]}$ In addition, it was reported that low $\mathrm{uE} 3$ levels $(<0.05 \mathrm{MoM})$ are also correlated with poor perinatal outcomes such as GHT, IUGR and oligohydramnios. ${ }^{[3,5,2]}$ In our study, we found that there is a significant correlation between $\mathrm{uE} 3$ level $<0.05 \mathrm{MoM}$ and the development of preeclampsia and HELLP syndrome.

In our study, we found a significant correlation between INH-A MoM being $\geq 2$ and developing GHT and HELLP syndrome. In these pregnant women, the risk for developing HELLP syndrome increased for 31 times and GHT for 9.4 times. INH-A is a glycoprotein in dimeric structure, synthesized in placental tissues and gonads, and it has two sub-units which are $\alpha$ and $\beta$. INH-A levels are quite high in the cases of triploid (except Down syndrome), HELLP syndrome and when one of the twins is aborted in the first trimester in twin pregnancies. INH-A levels are particularly low in the primary antiphospholipid antibody syndrome. ${ }^{[23]}$ In a study conducted, the authors found that INH-A level is higher in the women who developed gestational hypertension in concurrence with proteinuria during the second trimester. The authors reported that there is a significant correlation between INH-A MoM levels and GHT and HELLP syndrome. In addition, the authors stated that INH-A MoM level increases the risk of developing HELLP syndrome 31 times alone. ${ }^{[2]}$

Despite the clear correlations between abnormal serum marker values and undesired perinatal complications, no research showed that such screening methods are sufficiently sensitive and specific enough to use as a screening test for potential poor outcomes. Also, as it is not clear whether these distinct correlations are associated with other factors or not, it is unknown if such 
screening methods can be used in clinical settings safely or not. Wider studies with more patient populations did not investigate the correlations through advanced regression analyses by checking positive and negative predictive values to see if they are associated with other factors. However, under the light of the data, the clinicians should keep in mind that the screening tests conducted may predict undesired perinatal complications as well as detecting chromosomal diseases. In patients whose MoM values are in risk category in terms of preeclampsia, initiating low dose aspirin for prophylactic purposes may be a suitable approach although there is no study today proving that it is beneficial. ${ }^{[25]}$

\section{Conclusion}

As a result of our study, we are of the opinion that quad test as the second trimester screening test may predict perinatal complications and the results of quad screening tests may be a guide in terms of gestational complications. In our study, we found that AFP, hCG, uE3 and INH-A levels are correlated with the poor perinatal outcomes.

Pregnant women should be informed in detail about the potential gestational complications, the complications that may develop should be explained to them, and pregnant women should be assessed in detail and very carefully during pregnancy.

Conflicts of Interest: No conflicts declared.

\section{References}

1. Chitayat D, Langlois S, Wilson RD; Genetics Committee of the Society of Obstetricians and Gynaecologists of Canada; Prenatal Diagnosis Committee of the Canadian College of Medical Geneticists. Prenatal screening for fetal aneuploidy in singleton pregnancies. J Obstet Gynaecol Can 2011;33:73650 .

2. Currier R, Wu N, Van Meter K, Goldman S, Lorey F, Flessel $M$. Integrated and first trimester prenatal screening in California: program implementation and patient choice for follow-up services. Prenat Diagn 2012;32:1077-83.

3. Gündüz ÖD, Eser A, Çoban U, Tekeli S. Evaluation of the impact of triple test results on perinatal outcomes. Perinatal Journal 2016;24:26-3.

4. Alamillo CM, Krantz D, Evans M, Fiddler M, Pergament E. Nearly a third of abnormalities found after first-trimester screening are different than expected: 10-year experience from a single center. Prenat Diagn 2013;33:251-6.

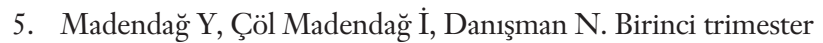
tarama testi belirteçlerinin intrauterin gelişme geriliği ile ilişkisi ve neonatal sonuçları üzerine etkisi. Jinekoloji Obstetrik ve Neonatoloji Tip Dergisi 2018;15:61-5.

6. Summers AM, Huang T, Meier C, Wyatt PR. The implications of a false positive second-trimester serum screen for Down syndrome. Obstet Gynecol 2003;101:1301-6.

7. Spencer K. Second-trimester prenatal screening for Down syndrome and the relationship of maternal serum biochemical markers to pregnancy complications with adverse outcome. Prenat Diagn 2000;20:652-6.

8. Sahin E, Col Madendag I, Sahin ME, Madendag Y, Acmaz G, Muderris II. Effect of vitamin D deficiency on the $75 \mathrm{~g}$ oral glucose tolerance test screening and insulin resistance. Gynecol Endocrinol 2019;35:535-8.

9. Tayyar AT, Karakus R, Sahin ME, Topbas NF, Sahin E, Karakus S, et al. Wnt signaling pathway in early- and lateonset preeclampsia: evaluation with Dickkopf-1 and RSpondin-3 glycoproteins. Arch Gynecol Obstet 2019;299: 1551-6.

10. Sahin ME, Col Madendag İ, Ak M. The effect of birth weight percentile on adverse neonatal morbidity in term uncomplicated pregnancies. Annals of Medical Research 2019;26:2535-9.

11. Madendag Y, Madendag IC, Sahin E, Aydin E, Sahin ME, Acmaz G. How well do the popular ultrasonic techniques estimate amniotic fluid volume and diagnose oligohydramnios, in fact? Ultrasound Q 2019;35:35-8.

12. Tayyar AT, Kozalı S, Yetkin Yildirim G, Karakus R, Yuksel IT, Erel O, et al. Role of ischemia-modified albumin in the evaluation of oxidative stress in intrahepatic cholestasis of pregnancy. J Matern Fet Neonat Med 2019;32:3836-40.

13. Ding L, Blitz MJ, Wing DA, Epstein AJ, Gjessing HK, Wilson ML. PHLDA2 gene polymorphisms and risk of HELLP syndrome and severe preeclampsia. Pregnancy Hypertension 2020; 19:190-4.

14. Dugoff L; Society for Maternal-Fetal Medicine. First and second trimester maternal serum markers for aneuploidy and adverse obstetric outcomes. Obstet Gynecol 2010;115:105261.

15. Fox H. Effect of hypoxia on trophoblast in organ culture: a morphologic and autoradiographic study. Am J Obstet Gynecol 1970;107:1058-64.

16. Cheng PJ, Chu DC, Chueh HY, See LC, Chang HC, Weng DR. Elevated maternal mid-trimester serum free beta-human chorionic gonadotropin levels in vegetarian pregnancies that cause increased false-positive Down syndrome screening results. Am J Obstet Gynecol 2004;190:442-7.

17. Crandall BF, Robinson L, Grau P. Risks associated with an elevated maternal serum alpha-fetoprotein level. Am J Obstet Gynecol 1991;165:581-6.

18. Walton DL, Norem CT, Schoen EJ, Ray GT, Colby CJ. Second-trimester serum chorionic gonadotropin concentrations and complications and outcome of pregnancy. N Engl J Med 1999;341:2033-8. 
19. Heinonen S, Ryynänen M, Kirkinen P, Saarikoski S. Elevated midtrimester maternal serum hCG in chromosomally normal pregnancies is associated with preeclampsia and velamentous umbilical cord insertion. Am J Perinat 1996;13:437-41.

20. Gagnon A, Wilson RD; Society of Obstetricians and Gynaecologists of Canada Genetics Committee. Obstetrical complications associated with abnormal maternal serum markers analytes. J Obstet Gynaecol Can 2008;30:918-32.

21. Summers AM, Langlois S, Wyatt P, Douglas Wilson R; Members of the SOGC Genetics Committee; Members of the CCMG Committee on Prenatal Diagnosis; Members of the SOGC Diagnostic Imaging Committee. Prenatal screening for fetal aneuploidy. J Obstet Gynaecol Can 2007;29:146-61.
22. Kim SY, Kim SK, Lee JS, Kim IK, Lee K. The prediction of adverse pregnancy outcome using low unconjugated estriol in the second trimester of pregnancy without risk of Down's syndrome. Yonsei Med J 2000;41:226-9.

23. Goodwin KM, Sweeney PJ, Lambert-Messerlian GM, Canick JA. High maternal serum inhibin A levels following the loss of one fetus in a twin pregnancy. Prenat Diagns 2000;20:1015-7.

24. Kim SY, Ryu HM, Yang JH, Kim MY, Ahn HK, Shin JS, et al. Maternal serum and amniotic fluid inhibin A levels in women who subsequently develop severe preeclampsia. J Korean Med Sci 2006;21:452-6.

25. ACOG Committee Opinion No. 743. Low-dose aspirin use during pregnancy. Obstet Gynecol 2018;132:e44-52.

Bu makalenin kullanım izni Creative Commons Attribution-NoCommercial-NoDerivs 3.0 Unported (CC BY-NC-ND3.0) lisansı aracılı̆̆ıly bedelsiz sunulmaktadir. / This work is licensed under the Creative Commons Attribution-NonCommercial-NoDerivs 3.0 Unported (CC BY-NC-ND3.0) License. To view a copy of this license, visit http://creativecommons.org/licenses/by-nc-nd/3.0/ or send a letter to Creative Commons, PO Box 1866, Mountain View, CA 94042, USA. 